\title{
SSC in New Delhi
}

The endangered wildlife of south-east Asia was especially highlighted in the February meetings of the SSC (Species Survival Commission) in New Delhi, notably of India, Bangladesh, Malaysia, Indonesia and Sabah. All these countries were represented, showing the value of moving the meeting place of this important IUCN Commission around the world. Members were able to congratulate particularly the Indian members present on the spectacular success of Project Tiger, whose Director, Shri B. H. Koppikar, was present. Rhinos, both African and Asian, also featured largely. Below are a few of the facts and figures presented to the meeting.

\section{Rhinos}

Africa. Black rhinos are declining in all countries; numbers are estimated at between 1300-2300. Northern white rhinos are down to under 1000, mainly in the Sudan and Zaire, with a handful in Uganda; southern white rhinos, estimated at 2000-2600, mostly in Natal, are increasing and more protected areas are needed for them. In February 1981 the Botswana Government destroyed all its stocks of rhino horn.

Asia. The great Indian rhino is increasing; numbers in India are put at 1600, including over 900 in the Kaziranga National Park in Assam. Many animals are now dispersed outside the national parks and reserves, and creating problems when they appear near villages. There are plans to translocate rhinos to both Jaldapara Wildlife Sanctuary, where there are about 28, and to Dudhwa National Park, where they disappeared more than 200 years ago. Jaldapara is to be enlarged.

Javan rhinos in Udjung Kulon National Park, in Java, the only known area for this species, are thought to be more numerous than the 50-odd shown in the last census, and they could outgrow the habitat. The possibility of moving some to an island is being considered.

Sumatran rhinos in Indonesia are inadequately guarded, and poachers still have to be reckoned with, even in the remote Gunung Loeser reserve. Three small populations in the proposed Kerinci reserve are totally unguarded.

In peninsular Malaysia numbers are put at 30-50, of which up to 35 are in national parks and reserves; in Sabah there may be as many as eight.

Operation Rhino. WWF has raised over $\$ 1.3$ million for the rhino campaign. Zambia has set up two very effective anti-poaching units in the Luangwa Valley $(\$ 400,000)$, and $\$ 300,000$ has gone to establish a new national park in the Sudan. Money has gone to Zaire's Garamba National Park for protection.

\section{Marine Turtles}

The proposal of developers to build a tourist hotel close to the main green-turtle Chelonia mydas nesting beach on Ascension Island in the South Atlantic has been 'set aside'.

Numbers of the Atlantic ridley turtle Lepidochelys kempi at the arribada (breeding assembly) in Mexico have gone down from a former 40,000 to around 400.

Off the west coast of Mexico over 100,000 green turtles are being taken annually. 
The lion-tailed macaque in India, one of the world's five most endangered monkeys, is down to very low numbers, estimated at about 400 , due to the amount of tropical evergreen forest destroyed. One of the only two viable populations is in the Silent Valley, where there are about 200 , but this is threatened with destruction by the building of a dam. Another threatened monkey, the Nilgiri langur, is doing well since the 1977 ban on all exports.

30,000 migrating wildebeest are reported to have died on the fence erected to keep foot and mouth disease out of Botswana. SSC has asked for an environmental impact statement.

Australia has set up a joint Inter-State/Federal Committee on Endangered Species, and kangaroo management is under discussion.

Tamed elephants are being successfully used in India to chase away crop-raiding wild elephants. In peninsular Malaysia electric fences have been erected in $\mathbf{4 6}$ areas to keep elephants out of crops.

Jordan is extending the Shaumari enclosed area for its Arabian oryx, now numbering 15 , to cover 15 square kilometres.

The revised management plan for Siberut, in Indonesia's Mentawai Islands, has doubled the size of the nature reserve to 100,000 ha. (See Oryx, November 1979, page 167.)

The endangered black-footed ferret Mustela nigripes in the USA has not been seen for two years.

\section{Introductions.}

Sport hunters in Germany have released Sylvilagus transitionalis, a species that can live in sub-alpine conditions, in central Europe. The cottontail rabbit S.floridanus introduced in Italy and southern France, is said to be successfully established in the Po valley.

Canadian beavers have been released in the USSR, where also Pacific coho salmon Oncorhynchus kisutch have been released into rivers draining into the Atlantic, and Pacific giant spider crabs into polar Atlantic waters.

An official campaign to exterminate three fruit fly pests in Hawaii with chemicals appears to have led to the extinction of one endemic bird (an amakihi), and, combined with pheromone traps, threatens several harmless native fruit flies.

When a sanctuary area was declared on the Crystal River in Florida, a historic area for manatees, and all boats banned, manatees immediately moved in. Damage by power-boat propellors is a serious cause of death and injury to manatees.

Argentina has designated Lago Pozuelos, in the altiplano, together with 200 sq miles of desert, a National Monument. Vicuna occur there and also Andean, James and Chilean flamingos.

\section{Correction}

Dr Perran Ross's study of the leatherback turtle Dermochelys coriacea, described in the December 1980 Oryx $(15,5$., page 430) took place in the Dominican Republic, not Dominica. We apologise for the mistake. 